\title{
Assessment of Land Suitability of Bilalgodu Micro-Watershed, Chikkamagaluru District, Karnataka for Optimal Agriculture Use Planning
}

\author{
B. Kalaiselvi ${ }^{1 *}$, Rajendra Hegde ${ }^{1}$, R. Vasundhara $^{1}$, S. Dharmarajan ${ }^{1}$ and S.K. Singh ${ }^{2}$ \\ ${ }^{1}$ ICAR-National Bureau of Soil Survey and Land Use Planning, Regional Centre, \\ Bangalore-560 024, India \\ ${ }^{2}$ ICAR-National Bureau of Soil Survey and Land Use Planning, Nagpur- 440 033, India \\ *Corresponding author
}

\begin{tabular}{|c|c|}
\hline \multicolumn{2}{|r|}{ A B S T R A C T } \\
\hline & \multirow{6}{*}{$\begin{array}{l}\text { Detailed soil resource inventorization was carried out at } 1: 7,920 \text { scale in Bilalgodu micro- } \\
\text { watershed, Mudigere taluk, Chikkamagaluru district with an objective to assess the land } \\
\text { suitability for various crops in the watershed. The soils of Bilalgodu micro-watershed are } \\
\text { characterised and classified into } 5 \text { soil series comprising of } 30 \text { mapping units. The soil site } \\
\text { characteristics and climatic factors were evaluated for its suitability for major existing } \\
\text { crops of the location viz., coffee, arecanut, coconut and rice. Nearly } 88 \% \text { soils of the } \\
\text { micro-watershed are highly suitable for coffee cultivation and remaining } 12 \% \text { are } \\
\text { moderately suitable with gravelliness limitations ( } 35-60 \%) \text {. Coconut is moderately suitable } \\
\text { for } 95 \% \text { area of micro-watershed with the constraints of erosion and gravelliness. Though } \\
\text { arecanut crop is occupying more cultivated area, the suitability is only marginal due to the } \\
\text { limitations of slope and erosion. In lowland soil (S5 series), rice is the predominantly } \\
\text { cultivated field crop in the watershed which is moderately suitable ( } 8 \% \text { TGA). Rice is not } \\
\text { suitable (N) for other soils except lowland soils mainly because of topography limitation } \\
\text { (l). Overall, Coffee is the highly suitable crop for Bilalgodu micro-watershed representing } \\
\text { Malnad region of Chikkamagaluru district, Karnataka. }\end{array}$} \\
\hline & \\
\hline $\begin{array}{l}\text { Inventorization, Land } \\
\text { suitability, Watershed, } \\
\text { Topography, } \\
\text { Gravelliness. }\end{array}$ & \\
\hline Article Info & \\
\hline $\begin{array}{l}\text { Accepted: } \\
\text { 10 September } 2017 \\
\text { Available Online: } \\
10 \text { November } 2017\end{array}$ & \\
\hline & \\
\hline
\end{tabular}

\section{Introduction}

Land and water are the most vital natural resources of the country and these are under tremendous stress due to ever increasing biotic pressure (Wani and Sidhu, 2009). The optimal management of these resources with minimum adverse environmental impact is essential, not only for sustainable development but also for human survival. Watershed is an ideal unit calling for multidisciplinary approach to the resources management for ensuring continuous benefit on sustainable basis. Integrated watershed management is a prerequisite not only for land, water and management of degraded areas for conservation and protection of areas so that bio-diversity and genetic resources are protected for future generations. Land Resource Inventory mapping plays a vital role in resource management. It assists in the planning for future land use, particularly agriculture, because it assesses the land resource and its potential for sustainable agricultural production. Productivity of a crop mainly depends on the land resources and the prevailing climate of the location. To enhance the production and productivity, the 
identification of crop requirements and meeting them with the available resources is essential for the present situation of food demands (Sehgal, 1991). Each crop requires specific soil site conditions for its growth. For rationalized use, the soil- site suitability for different crops needs to be determined. To achieve this, detailed land resource inventorization was carried out in Bilalgodu micro-watershed, Mudigere Taluk, Chikkamagaluru district at 1:7,920 scale.

\section{Materials and Methods}

\section{Study area}

Bilalgodu micro-watershed is located in Kalasa Hobli, Mudigere taluk of Chikkamagaluru district. The microwatershed with total area of 710 hectares lies between $75^{\circ} 17^{\prime} 54^{\prime \prime}$ and $75^{\circ} 20^{\prime} 03^{\prime \prime}$ E longitude and $13^{\circ} 11^{\prime} 54^{\prime \prime}$ and $13^{\circ} 13^{\prime} 49^{\prime \prime} \mathrm{N}$ latitude. The general elevation of the area ranges from 700 to $1100 \mathrm{~m}$ above mean sea-level (MSL). The slope ranges between gently sloping (3-5\%) and strongly sloping (10-15 \%). The physiography of the watershed can be broadly divided into uplands (summit and ridge top), side slopes and colluvial valley/lowlands. Rolling to steep sloping land covers around $70 \%$ of the area in this micro watershed. Terracing is the common practice for field crops in this area whereas in the summit and side slopes, the coffee, arecanut and coconut are the major cultivating crops. It comes under agro ecological sub region (AESR) of 19.2- hot, moist, sub humid to humid with the annual precipitation is $2000-3000 \mathrm{~mm}$. The average annual temperature is $22.5^{\circ} \mathrm{C}$ and the LGP ranges from 210-270 days (Fig. 1). High rainfall and well-drained soil favouring the growth of plantation crops like coffee, arecanut, coconut and rubber are grown successfully in the area. Natural vegetations of this area are Eucalyptus grandis, Tectona grandis (Teak), Jack fruit, Bamboo (Dendroclamus asper), Ficus religiosa,
Eupatorium odoratum, Clerodendron (Clerodendrum infortunatum), Caryota urens, Mimosa pudica, other thorny plants and creepers, with grass cover below.

\section{Base map used}

Detail survey of the watershed was carried out by using cadastral map as a base. The cadastral map shows field boundaries with their survey numbers, location of tanks, streams and other permanent features of the area. Remote sensing data products from IRSP6 - LISS IV and Cartosat-1(ortho-corrected) at the same scale were used in conjunction with the cadastral maps to identify the landforms and other surface features. Imageries helped in the identification and delineation of boundaries between hills, uplands and lowlands, water bodies, forest and vegetated areas, roads, habitations and other cultural features of the area.

\section{Field investigations}

Preliminary traverse of the micro watershed was carried out by using cadastral map which shows field boundaries. During the traverse geological formations, drainage patterns, surface features, slope characteristics, landforms and land use patterns of the area were identified based on the initial traversing. The high intensity detailed soil survey (at 1:7,920 scale) was carried out. Three transects were selected to study the profile at closely spaced intervals to take care of any change in the land features like break in slope, erosion, gravels, stones etc. At selected sites profiles were opened up to 2 meter or shallow depth limited by rock or hard substratum. Profiles were studied in detail for all their morphological and physical characteristics. The detailed study of watershed area includes site characteristics (like slope of the land, erosion, drainage, occurrence of rock fragments etc.) and soil characteristics (like depth, texture, colour, structure, consistency, 
coarse fragments, porosity, soil reaction etc.) (Soil survey staff, 2003), followed by grouping of similar areas based on soil-site characteristics into homogenous (management) units and showing their extent and distribution on the village cadastral map. Based on the soil site and climatic properties, the soil site suitability was assessed for the major existing crops (Naidu et al., 1996). The soil site suitability was categorized into Highly suitable (S1)- Land suitable for plant growth without or with only slight correctable limitations, Moderately suitable (S2)- Nearly optimal conditions, affect productivity, have slight and no more than 3 moderate limitations, Marginally suitable (S3)- Land unit represents moderate condition that affects productivity significantly but still marginally economical and Not suitable (N)- Land unit having limitations that appears to preclude its sustained use of the kind under consideration and labelled with subclasses (limitations) suffixed. Soil and soil- site suitability maps were prepared from ArcGIS 10.2.2 software.

\section{Results and Discussion}

\section{Soils of Bilalgodu micro-watershed}

The micro-watershed is broadly divided into three distinct landforms, uplands, side slopes and lowlands/valleys. According to the land forms, surface features and the land use, the soil- site characteristics have been studied, collected and characterised for soil physical, chemical and physic-chemical properties. Through the detailed characterisation, 5 soil series with 30 phases were identified (Fig. 2). Out of this, four soil series occur in the gently sloping to steep sloping upland areas and one soil series occur in the lowland area. Out of the five soil series identified, S3 series occur extensively, occupying about 45.2 per cent area of the upland followed by S1 and S4. The series S1 and S4 combinly occupies about 367 ha of the watershed. The one lowland series (S5) occupy about 56.4 ha (7.9 $\%)$ in the watershed. The extent of the soil series and their phases mapped in the watershed is given in the table 1 .

\section{Assessment of soil-site suitability for crops}

The optimum requirements of a crop are always region specific. Climate and soil-site parameters play significant role to maximize the crop yields. The existing crops of the microwatershed are coffee, coconut, arecanut and paddy. Suitability criteria for the present existing crops were assessed with the properties of watershed soil and prepared as thematic maps. Assessing the extent and degree of suitability of the land resources in the village for various crops is necessary to choose the right crop and variety suitable for the area. In carrying out this assessment, the specific requirements of a crop (compiled from the existing literature) are compared with the characteristics of land and based on the extent of matching; the suitability of the area for the crop is arrived (Naidu et al., 2006) (Table 2). Then by comparing the relative suitability of the resources for different uses, an ideal combination of crops suitable for a particular farm within the village area can be selected.

\section{Land suitability for coffee (Coffee arabica)}

Coffee is the major plantation crop in high rainfall areas of high altitude. It can grow in the steep sloping land as well as in $3000 \mathrm{~mm}$ rainfall. The crop may be grown on any type of soil but loamy soils are preferred. Very deep, well drained, non-calcareous, and nonsaline soils are best suited for the crop. The suitability assessment for coffee in Bilalgodu watershed showed that nearly 88.5 per cent of area is highly suitable due to depth of soil, gravelliness, drainage and topography (Fig. 3) followed by 7 per cent area is moderately suitable with 35-60 \% gravelliness. 
Table.1 Soil phase description and distribution of Bilalgodu micro-watershed

\begin{tabular}{|c|c|c|c|}
\hline Sl No. & Map symbol & Description & Area (ha) \\
\hline 1. & $\mathrm{~S} 1 \mathrm{fC} 2$ & $\begin{array}{l}\text { Deep, well drained, clay loam, occurring on rolling slope. Clay loam } \\
\text { surface, slope 3-5\%, Moderate erosion. }\end{array}$ & 1.6 \\
\hline 2. & S1fC3 & $\begin{array}{l}\text { Deep, well drained, clay loam, occurring on rolling slope. Clay loam } \\
\text { surface, slope } 3-5 \% \text {, Severe erosion. }\end{array}$ & 35.5 \\
\hline 3. & S1fD2 & $\begin{array}{l}\text { Deep, well drained, clay loam, occurring on rolling slope. Clay loam } \\
\text { surface, slope } 5-10 \% \text {, Moderate erosion. }\end{array}$ & 40.4 \\
\hline 4. & S1fD3 & $\begin{array}{l}\text { Deep, well drained, clay loam, occurring on rolling slope to hilly } \\
\text { sloping uplands. Clay loam surface, slope } 5-10 \% \text {, Severe erosion. }\end{array}$ & 14.6 \\
\hline 5. & $\mathrm{~S} 1 \mathrm{hD} 2 \mathrm{~g} 1$ & $\begin{array}{l}\text { Deep, well drained, sandy clay loam, occurring on rolling slope to } \\
\text { hilly sloping uplands. Sandy clay loam surface, slope } 5-10 \% \text {, } \\
\text { Moderate erosion. slightly gravelly }(15-35 \%) \text {. }\end{array}$ & 21.9 \\
\hline 6. & S1hE2g1 & $\begin{array}{l}\text { Deep, well drained, sandy clay loam, occurring on hilly sloping to } \\
\text { steep sloping uplands. Sandy clay loam surface, slope } 10-15 \% \text {, } \\
\text { Moderate erosion. slightly gravelly }(15-35 \%) \text {. }\end{array}$ & 21.5 \\
\hline 7. & S1mD3 & $\begin{array}{l}\text { Deep, well drained, clay soil, occurring rolling sloping to hilly side } \\
\text { slopes. Clay surface, slope } 5-10 \% \text {, severe erosion. }\end{array}$ & 17.2 \\
\hline 8. & $\mathrm{~S} 2 \mathrm{fD} 2$ & $\begin{array}{l}\text { Deep, well drained, clay loam soil, occurring rolling sloping to hilly } \\
\text { side slopes. Clay loam surface, slope } 3-5 \% \text {, moderate erosion. }\end{array}$ & 5.8 \\
\hline 9. & $\mathrm{~S} 2 \mathrm{fE} 3 \mathrm{~g} 1$ & $\begin{array}{l}\text { Deep, well drained, clay loam soil, occurring rolling sloping to hilly } \\
\text { side slopes. Clay loam surface, slope } 10-15 \% \text {, severe erosion, 15-35 } \\
\% \text { fine gravels. }\end{array}$ & 13.1 \\
\hline 10. & $\mathrm{~S} 2 \mathrm{hC} 3$ & $\begin{array}{l}\text { Deep, well drained, sandy clay loam soil, occurring rolling sloping to } \\
\text { hilly side slopes. Sandy clay loam surface, slope } 3-5 \% \text {, severe } \\
\text { erosion. }\end{array}$ & 10.3 \\
\hline 11. & $\mathrm{~S} 2 \mathrm{hD} 3$ & $\begin{array}{l}\text { Deep, well drained, sandy clay loam soil, occurring rolling sloping to } \\
\text { hilly side slopes. Sandy clay loam surface, slope } 5-10 \% \text {, severe } \\
\text { erosion. }\end{array}$ & 8.3 \\
\hline 12. & S3fB2 & $\begin{array}{l}\text { Very deep, well drained, clay loam soil, occurring rolling sloping to } \\
\text { hilly side slopes. Clay loam surface, slope } 1-3 \% \text {, moderate erosion. }\end{array}$ & 3.2 \\
\hline 13. & $\mathrm{~S} 3 \mathrm{fC} 2$ & $\begin{array}{l}\text { Very deep, well drained, clay loam soil, occurring rolling sloping to } \\
\text { hilly side slopes. Clay loam surface, slope } 3-5 \% \text {, moderate erosion. }\end{array}$ & 19.0 \\
\hline 14. & S3fC3 & $\begin{array}{l}\text { Very deep, well drained, clay loam soil, occurring rolling sloping to } \\
\text { hilly side slopes. Clay loam surface, slope } 3-5 \% \text {, severe erosion. }\end{array}$ & 46.5 \\
\hline 15. & S3fD2 & $\begin{array}{l}\text { Very deep, well drained, clay loam soil, occurring rolling sloping to } \\
\text { hilly side slopes. Clay loam surface, slope } 5-10 \% \text {, moderate erosion. }\end{array}$ & 96.6 \\
\hline
\end{tabular}




\begin{tabular}{|c|c|c|c|}
\hline 16. & S3fD3 & $\begin{array}{l}\text { Very deep, well drained, clay loam soil, occurring rolling sloping to } \\
\text { hilly side slopes. Clay loam surface, slope } 5-10 \% \text {, severe erosion. }\end{array}$ & 43.3 \\
\hline 17. & S3fE3g2 & $\begin{array}{l}\text { Very deep, well drained, clay loam soil, occurring rolling sloping to } \\
\text { hilly side slopes. Clay loam surface, slope } 10-15 \% \text {, severe erosion } \\
\text { and }>35 \% \text { fine gravels. }\end{array}$ & 27.6 \\
\hline 18. & $\mathrm{~S} 3 \mathrm{hC} 2$ & $\begin{array}{l}\text { Very deep, well drained, sandy clay loam soil, occurring rolling } \\
\text { sloping to hilly side slopes. Sandy clay loam surface, slope } 1-3 \% \text {, } \\
\text { moderate erosion }\end{array}$ & 4.6 \\
\hline 19. & S3hD3 & $\begin{array}{l}\text { Very deep, well drained, sandy clay loam soil, occurring rolling } \\
\text { sloping to hilly side slopes. Sandy clay loam surface, slope 5-10\%, } \\
\text { severe erosion. }\end{array}$ & 3.9 \\
\hline 20. & $\mathrm{~S} 3 \mathrm{mD} 3$ & $\begin{array}{l}\text { Very deep, well drained, clay soil, occurring rolling sloping to hilly } \\
\text { side slopes. clayey surface, slope } 5-10 \% \text {, severe erosion }\end{array}$ & 56.8 \\
\hline 21. & $\mathrm{~S} 3 \mathrm{mD} 3 \mathrm{~g} 2$ & $\begin{array}{l}\text { Very deep, well drained, gravelly clay soil, occurring rolling sloping } \\
\text { to hilly side slopes. clayey surface, slope 5-10\%, severe erosion and } \\
15-35 \% \text { fine gravels. }\end{array}$ & 19.4 \\
\hline 22. & $\mathrm{~S} 4 \mathrm{fC} 2$ & $\begin{array}{l}\text { Very deep, well drained, Clay loam soil, occurring on rolling slope. } \\
\text { Clay loam surface, slope 5-10\%, moderate erosion. }\end{array}$ & 18.5 \\
\hline 23. & $\mathrm{~S} 4 \mathrm{fC} 3$ & $\begin{array}{l}\text { Very deep, well drained, Clay loam soil, occurring on rolling slope. } \\
\text { Clay loam surface, slope } 3-5 \% \text {, Severe erosion. }\end{array}$ & 11.5 \\
\hline 24. & $\mathrm{~S} 4 \mathrm{fD} 2$ & $\begin{array}{l}\text { Very deep, well drained, Clay loam soil, occurring on rolling slope. } \\
\text { Clay loam surface, slope 5-10\%, moderate erosion. }\end{array}$ & 21.5 \\
\hline 25. & S4fD3 & $\begin{array}{l}\text { Very deep, well drained, Clay loam soil, occurring on rolling slope. } \\
\text { Clay loam surface, slope 5-10\%, Severe erosion. }\end{array}$ & 11.5 \\
\hline 26. & $\mathrm{~S} 4 \mathrm{hD} 2$ & $\begin{array}{l}\text { Very deep, well drained, Sandy clay loam soil, occurring on rolling } \\
\text { slope. Sandy clay loam surface, slope } 5-10 \% \text {, moderate erosion. }\end{array}$ & 14.2 \\
\hline 27. & $\mathrm{~S} 4 \mathrm{hD} 2 \mathrm{~g} 1$ & $\begin{array}{l}\text { Very deep, well drained, gravelly Sandy clay loam soil, occurring on } \\
\text { rolling slope. Sandy clay loam surface, slope } 5-10 \% \text {, moderate } \\
\text { erosion and } 15-35 \text { per cent fine gravels. }\end{array}$ & 14.2 \\
\hline 28. & S4mD3 & $\begin{array}{l}\text { Very deep, well drained, clayey soil, occurring on nearly leveled } \\
\text { valleys. Clay surface, slope } 5-10 \% \text {, severe erosion. }\end{array}$ & 19.2 \\
\hline 29. & S5fB2 & $\begin{array}{l}\text { Very deep, well drained, clay loam soil, occurring on nearly leveled } \\
\text { valleys. Clay loam surface, slope 1-3\%, moderate erosion. }\end{array}$ & 57.6 \\
\hline 30. & $\mathrm{~S} 5 \mathrm{fC} 2$ & $\begin{array}{l}\text { Very deep, well drained, clay loam soil, occurring on nearly leveled } \\
\text { valleys. Clay loam surface, slope 3-5 \%, moderate erosion. }\end{array}$ & 3.4 \\
\hline 31. & ROCK OUT & & 2.0 \\
\hline 32. & Water bodies & & 22.9 \\
\hline
\end{tabular}


Table.2 Soil site suitability criteria for Coffee, Arecanut, Coconut and Rice (Naidu et al., 2006)

\begin{tabular}{|c|c|c|c|c|c|}
\hline Soil site characteristics & Unit & Highly suitable (S1) & Moderately suitable (S2) & Marginally suitable (S3) & Not suitable $(\mathrm{N})$ \\
\hline \multicolumn{6}{|l|}{ Coffee (Coffea arabica) } \\
\hline Mean temperature & ${ }^{\circ} \mathrm{C}$ & $20-24$ & $15-19 ; 25-26$ & $12-13 ; 27-28$ & $<12 ;>28$ \\
\hline Elevation & $\mathrm{m}$ & $800-1500$ & $700-800 ; 1500-1800$ & $300-700 ; 1800-2000$ & $<300 ;>2000$ \\
\hline Total rainfall & $\mathrm{mm}$ & $>1100$ & $1000-1100$ & $800-1000$ & $<800$ \\
\hline Soil drainage & Class & Well drained & Moderately well drained & Imperfect to poorly drained & Poorly drained \\
\hline Texture & $\mathrm{cm}$ & 1, scl, sicl, cl, sc, c & 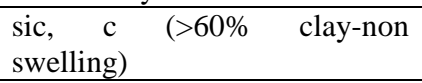 & sl & $\begin{array}{l}\text { ls, s, c (>60\% clay- } \\
\text { swelling) }\end{array}$ \\
\hline CEC & $\mathrm{C} \mathrm{mol}(\mathrm{p}+) \mathrm{kg}^{-1}$ & $>16$ & $12-16$ & $<12$ & - \\
\hline Organic carbon & $\%$ & $>1.0$ & $0.6-1.0$ & $<0.6$ & - \\
\hline Soil depth & $\mathrm{cm}$ & $>100$ & $75-100$ & $50-75$ & $<50$ \\
\hline Coarse fragments & $\%$ & $<35$ & $35-60$ & $60-75$ & $>75$ \\
\hline Slope & $\%$ & $1-15$ & $15-35$ & $35-50$ & $>50$ \\
\hline \multicolumn{6}{|c|}{ Arecanut (Areca catechu L.) } \\
\hline Mean temperature & ${ }^{\circ} \mathrm{C}$ & $25-30$ & $20-24 ; 31-35$ & $15-19 ; 36-40$ & $>40 ;<15$ \\
\hline Total rainfall & $\mathrm{mm}$ & $>1500$ & $1000-1500$ & $500-<1000$ & \\
\hline Soil drainage & Class & Well drained & Moderately well drained & $\begin{array}{l}\text { Imperfect drained, } \\
\text { excessively drained }\end{array}$ & Poorly drained \\
\hline Texture & Class & $\mathrm{cl}, \mathrm{scl}, \mathrm{sc}, \mathrm{sicl}, \mathrm{sil}$ & sl, c, sic & $\mathrm{c}, \mathrm{ls}, \mathrm{s}$ & \\
\hline Soil depth & $\mathrm{cm}$ & $>100$ & $75-100$ & $50-75$ & $<50$ \\
\hline Coarse fragments & $\%$ & $<15$ & $15-35$ & $35-50$ & $>50$ \\
\hline Slope & $\%$ & $<3$ & $3-5$ & $5-10$ & \\
\hline \multicolumn{6}{|c|}{ Coconut (Cocos nucifera L.) } \\
\hline Mean temperature & ${ }^{\circ} \mathrm{C}$ & $26-29$ & $23-25 ; 30-32$ & $20-22 ; 33-34$ & \\
\hline Total rainfall & $\mathrm{mm}$ & $1500-2500$ & $1000-1500$ & $500-1000$ & $<500$ \\
\hline Soil drainage & Class & Well drained & Moderately well drained & $\begin{array}{l}\text { Imperfectly drained, } \\
\text { excessively drained }\end{array}$ & Poorly drained \\
\hline Texture & Class & $\mathrm{cl}, \mathrm{scl}, \mathrm{sc}, \mathrm{sicl}, \mathrm{sil}$ & $\mathrm{sl}, \mathrm{c}, \mathrm{sic}$ & $\mathrm{c}, \mathrm{ls}, \mathrm{s}$ & \\
\hline Soil depth & $\mathrm{cm}$ & $>100$ & $75-100$ & $50-75$ & $<50$ \\
\hline Coarse fragments & $\%$ & $<15$ & $15-35$ & $35-50$ & $>50$ \\
\hline Slope & $\%$ & $<8$ & $8-15$ & $15-30$ & \\
\hline \multicolumn{6}{|l|}{ Rice (Oryza sativa L.) } \\
\hline Mean temperature & ${ }^{\circ} \mathrm{C}$ & $30-34$ & $21-29 ; 35-38$ & $15-20 ; 39-40$ & $>40 ;<15$ \\
\hline Total rainfall & $\mathrm{mm}$ & $1110-1250$ & $900-1110$ & $750-900$ & $<750$ \\
\hline Soil drainage & Class & Imperfectly drained & Moderately well drained & $\begin{array}{l}\text { Well drained; somewhat } \\
\text { excessively drained }\end{array}$ & Excessively drained \\
\hline Texture & Class & $\mathrm{s}, \mathrm{sic}, \mathrm{cl}, \mathrm{sicl}, \mathrm{sc}$ & scl, sil, 1 & $\mathrm{sl}, \mathrm{ls}$ & $\mathrm{s}$ \\
\hline Soil depth & $\mathrm{cm}$ & $>75$ & $51-75$ & $25-50$ & \\
\hline $\mathrm{CaCO}_{3}$ in root zone & $\%$ & $<15$ & $15-25$ & $25-30$ & $>30$ \\
\hline Slope & $\%$ & $0-1$ & $1-3$ & $3-5$ & $>5$ \\
\hline
\end{tabular}


Fig.1 Rainfall distribution and PET of Mudigere taluk, Chikkamagaluru district

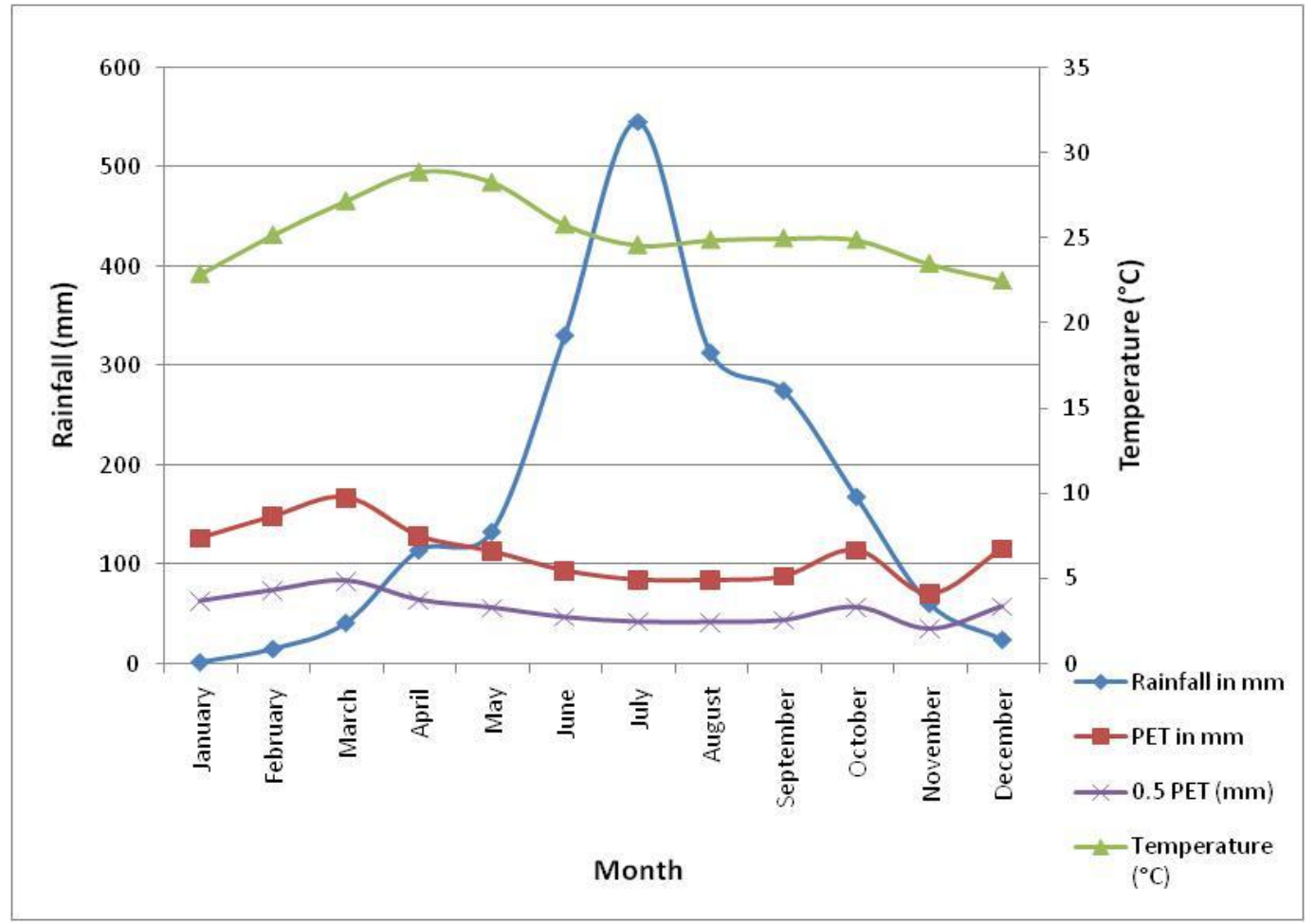

Fig.2 Soils of Bilalgodu micro-watershed, Mudigere taluk, Chikkamagaluru district

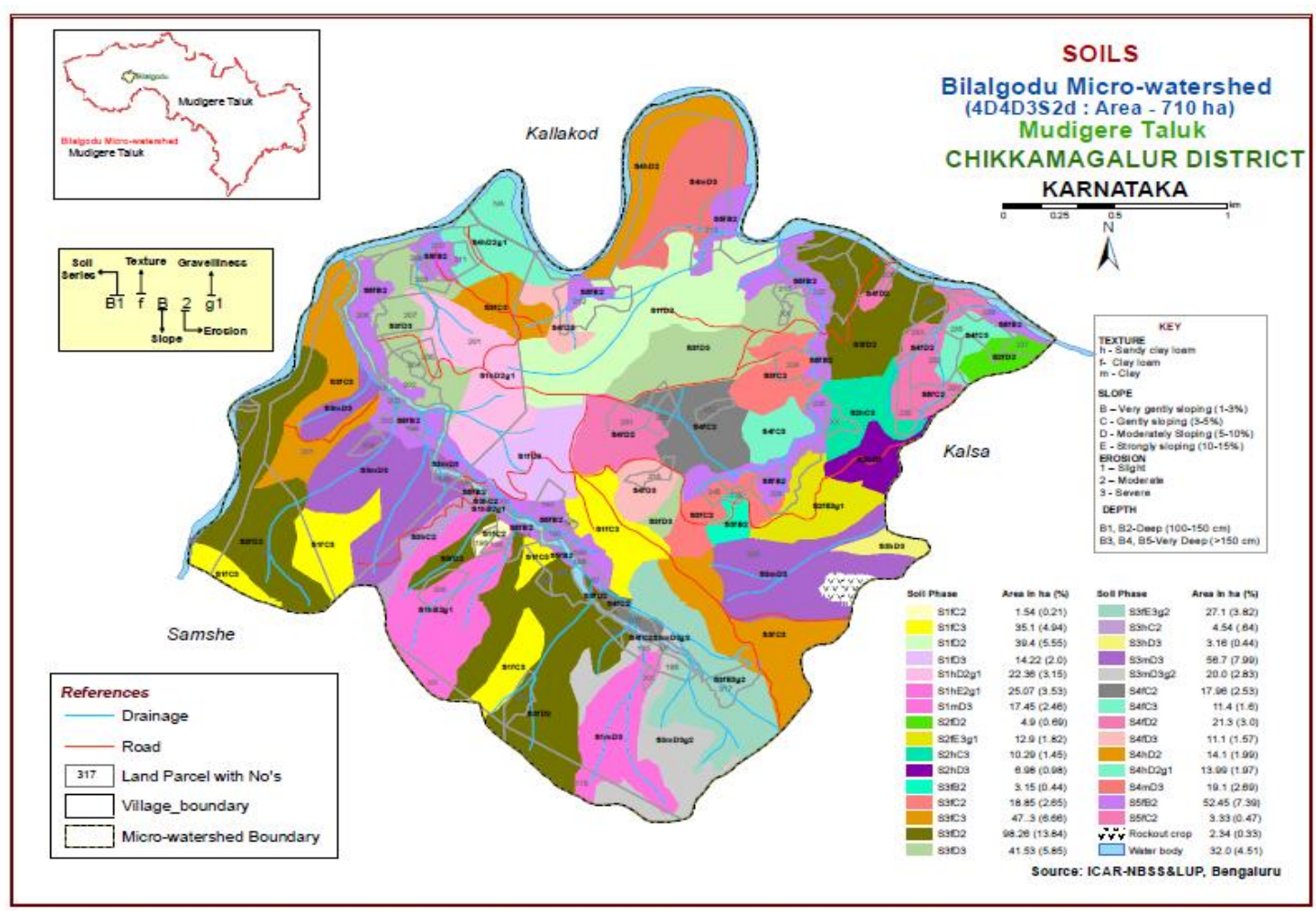


Fig.3 Land suitability map for coffee in Bilalgodu micro-watershed

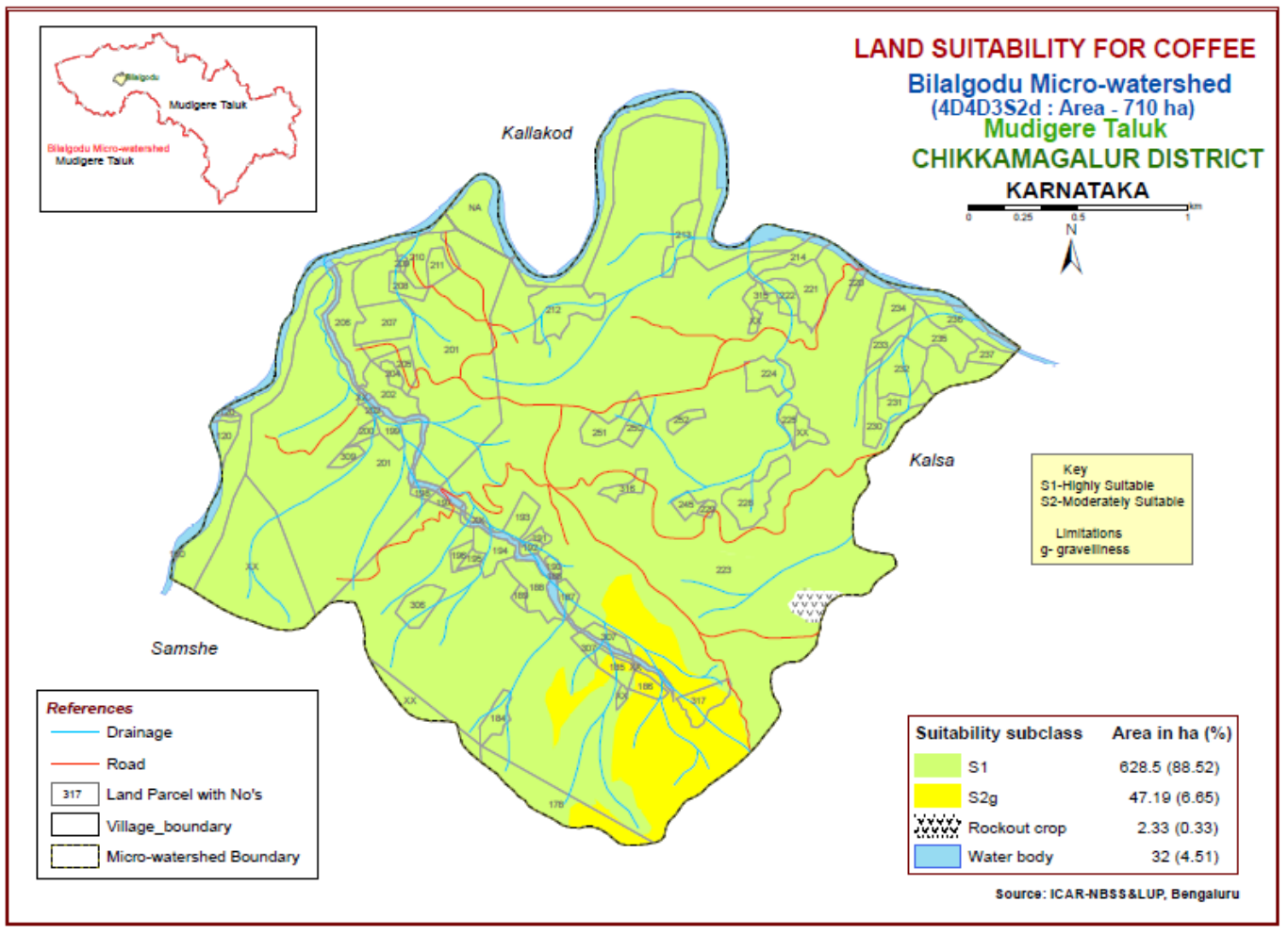

Fig.4 Land suitability map for coconut in Bilalgodu micro-watershed

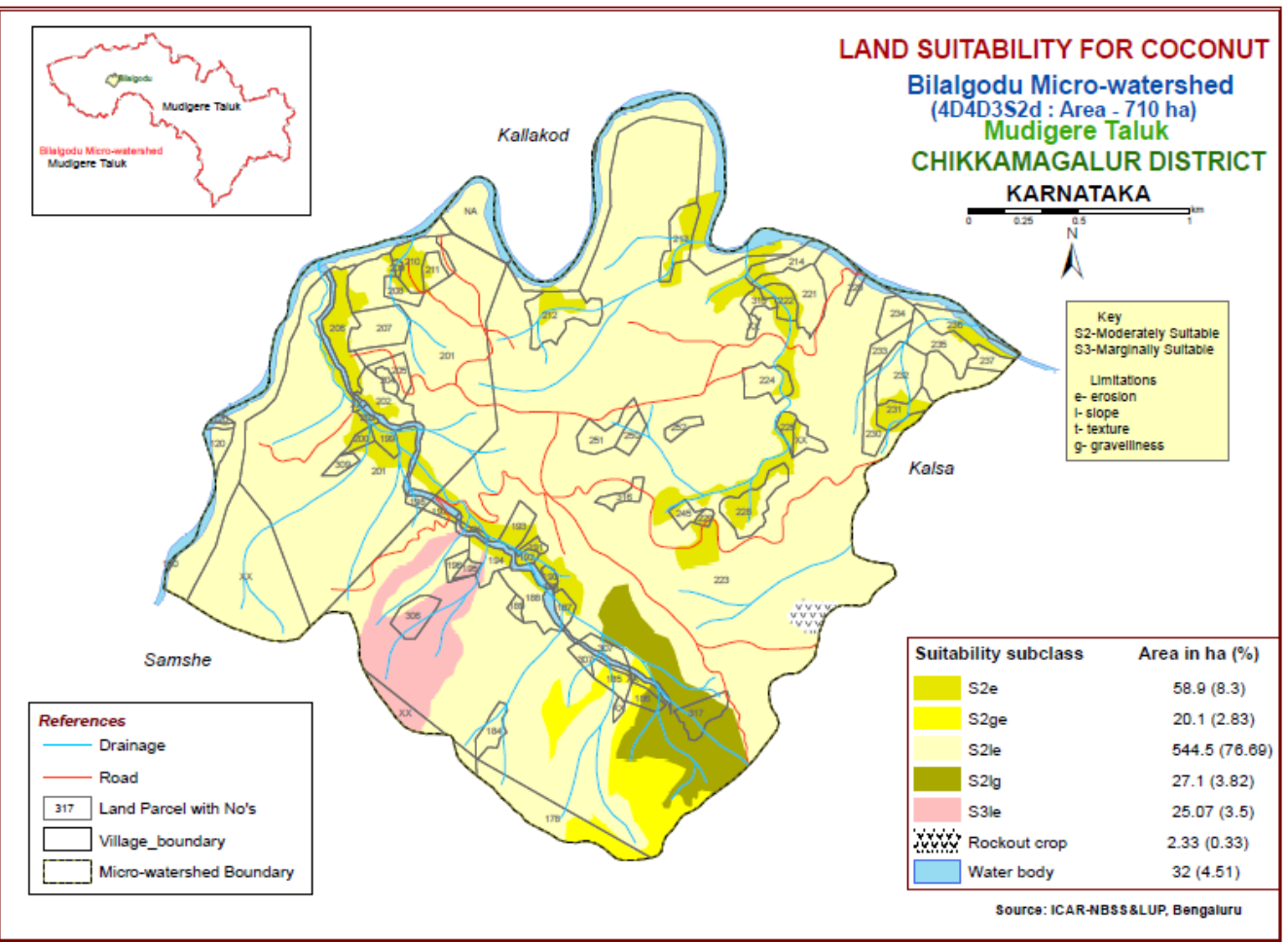


Fig.5 Land suitability map for arecanut in Bilalgodu micro-watershed

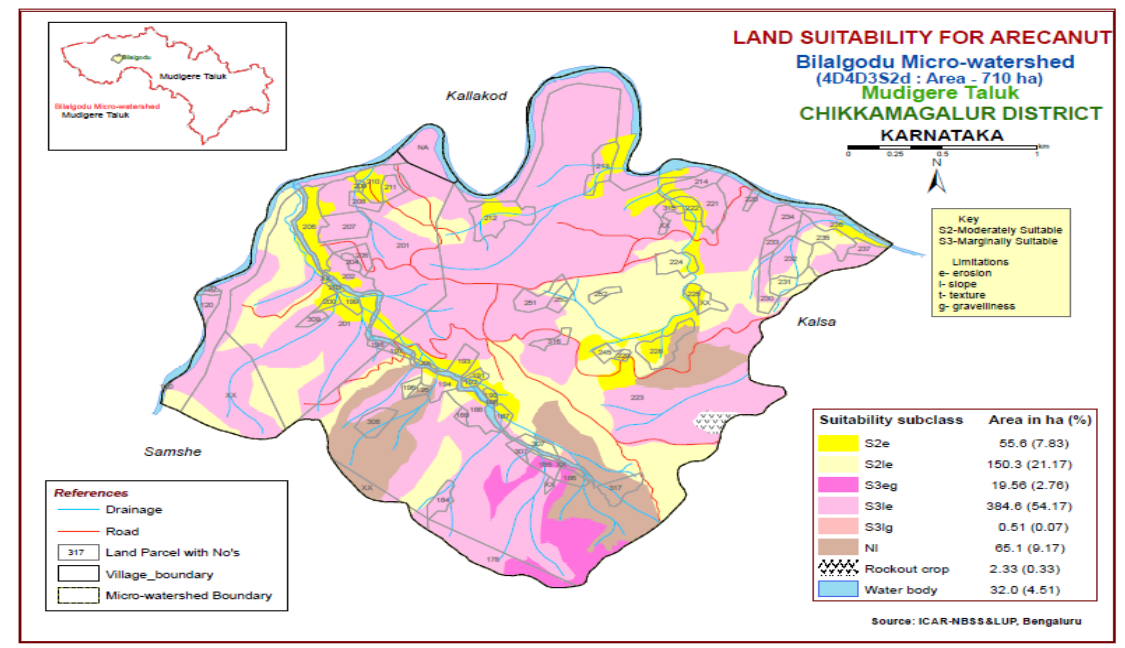

Fig.6 Land suitability map for rice in Bilalgodu micro-watershed

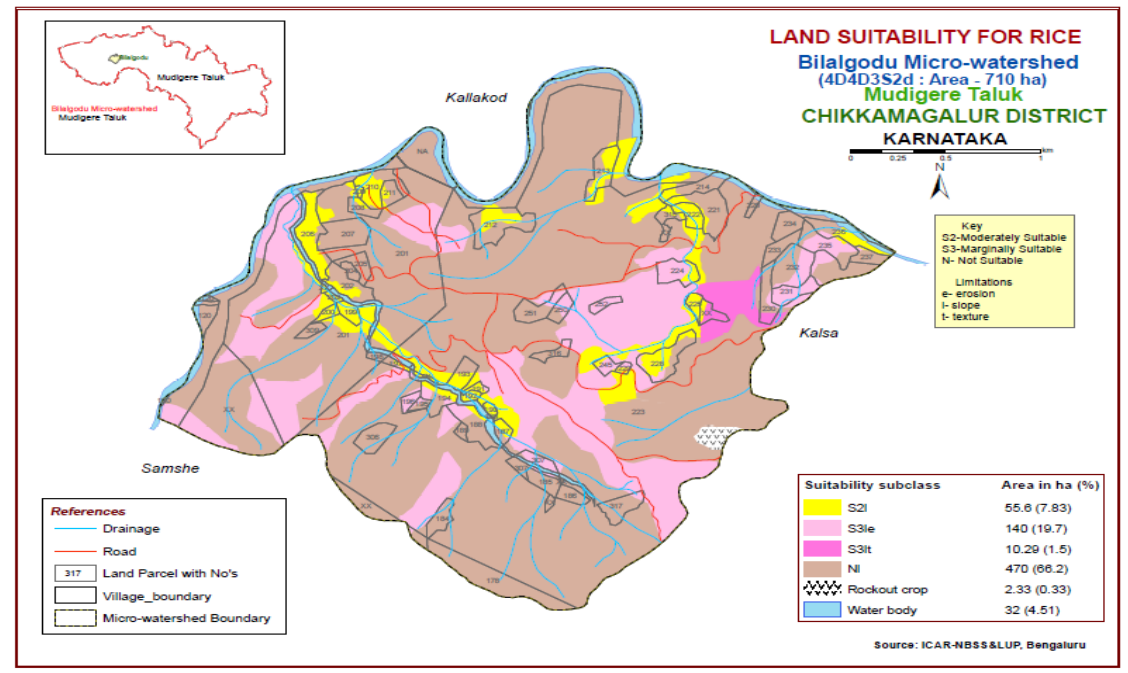

Land suitability for Coconut (Cocus nucifera)

Coconut is a promising and well adopted crop for the area. It can be grown under varying climatic and soil conditions throughout the year in India. It can be cultivated in all types of soils ranging from poor to highly fertile soils, though it performs well in the soil having good fertility, proper drainage, good water-holding capacity and no hard substratum within $2 \mathrm{~m}$ depth. It is highly salt tolerant and can be grown even in strongly alkaline soils. The essential requirement of the crop is water. The 91 per cent area of Bilalgodu micro-watershed is moderately suitable with varying level of constraints like erosion and slope, gravellines and texture (Fig. 4). Around 4 per cent of the watershed area is marginally suitable with major limitations of slope and erosion.

\section{Land suitability for arecanut (Areca catechu)}

Arecanut is capable of growing in a variety of soils. It thrives best in well drained soils. Adequate protection from exposure to South- 
Western sun is essential to avoid sun-scorch. Quick growing shade trees have to be planted on the southern and western sides well in advance of planting seedlings. It is sensitive to moisture deficit and should be grown where adequate water facilities are available. Due to these above mentioned requirements for the growth of arecanut, the bilalgodu soil is comparatively suitable for arecanut plantation (Fig. 5). About 30 per cent of the soil is moderately and around 56 per cent of the soil is marginally suitable for arecanut cultivation with the advantages of natural thin forest vegetation as well as with the limitations of slope, erosion and gravelliness.

\section{Land suitability for rice (Oryza sativa L.)}

It is the traditional and major cereal crop of south India. Though the Bilalgodu microwatershed is located in high altitude, high rainfall area, in lowlands of this region, rice is the major cultivated crop. Clay enriched soils of this watershed after puddling easily creates the impervious soil layer which is essential for rice cultivation. The high organic matter content of the soil enhances the crop growth. The suitability assessment for rice in the Bilalgodu showed that nearly 8 per cent of area is moderately suitable and nearly 20 per cent area is marginally suitable. Around 70 per cent area are not suitable for rice cultivation because of the steep slope nature of the land. The main constraints are eroded soils, slope, texture and gravelliness in moderately suitable areas (Fig. 6). The hilly areas and sloping upland areas were permanently not suitable due to very severe limitations of drainage and slope. The other uplands and midlands were marginally suitable, due to slope, erosion and drainage whereas lowlands were moderately to highly suitable due to moderate limitations of climate and fertility factors.

Soil properties and its suitability for the existing crops of the watershed were evaluated. The coffee is highly suitable crop followed by coconut in the study area irrespective of soil type and stage of crop. The productivity of arecanut and rice were limited due to constraints of gravelliness, slope and erosion. Based on the land suitability, the soil conservation measures can be adopted to control the impact of slope and erosion in Bilalgodu micro-watershed.

\section{References}

FAO. 1976. A Framework for Land Evaluation, Soils Bulletin, 32, Food and Agriculture Organization, Rome.

Naidu, L.G.K., V. Ramamurthy, O. Challa, Rajendra Hegde and P. Krishnan, 2006. Manual for soil-site suitability criteria for major crops, NBSS\&LUP Publication. 129.

Sehgal, J.L. 1996. Pedology - Concepts and applications. Kalyani publishers, New Delhi, India.

Soil Survey Staff. 2003. 'Keys to Soil Taxonomy'. Ninth Edition, USDA, Washington, DC,

Wani, S.P., and G.S. Sidhu. 2009. Land Use Planning in Integrated Watershed Development Program for Improving Livelihoods. Indian Society of Soil Science- Platinum Jubilee Symposium Proceedings, pp.154-164.

\section{How to cite this article:}

Kalaiselvi, B., Rajendra Hegde, R. Vasundhara, S. Dharmarajan and Singh, S.K. 2017. Assessment of Land Suitability of Bilalgodu Micro-Watershed, Chikkamagaluru District, Karnataka for Optimal Agriculture Use Planning. Int.J.Curr.Microbiol.App.Sci. 6(11): 11461155. doi: https://doi.org/10.20546/ijcmas.2017.611.137 